\title{
APLIKASI PENGHITUNG UPAH LEMBUR BERDASARKAN JUMLAH WAKTU LEMBUR DENGAN MENGGUNAKAN ALGORITMA LINEAR SEARCH
}

\author{
Hendra Kurniawan ${ }^{1}$, Sabar Rudiarto ${ }^{2}$ \\ ${ }^{1}$ Universitas Mercu Buana \\ ${ }^{2}$ Universitas Mercu Buana \\ E-mail:41513120129@student.mercubuana.ac.id ${ }^{1}$, \\ sabar.rudiarto@mercubuana.ac.id ${ }^{2}$
}

\begin{abstract}
The development of information technology has created many solutions to problems that are often faced in life. An application can help a job and make it easier has encourage companies to use applications that help their work in several departments such as administration and human resources. Some companies have regulations requiring employees to do work more than normal working hours that called overtime. Every employee who does overtime will get overtime wages accordance to the amount of overtime that has been done. But sometimes the late of payments occurred because the calculation of overtime wages takes a long time when many employees did overtime. To solve this problem the company needs an application that can calculate overtime wages quickly and accurately, using the linear search algorithm application will search and process the recorded data in the attendance machine, then calculate overtime wages according to the amount of overtime that has been done. And then it can minimize the occurrence of late payments and more accurate calculations result.
\end{abstract}

Keywords: application, offices, human resources, overtime wages, salary, automation

\begin{abstract}
ABSTRAK
Perkembangan teknologi informasi telah menciptakan banyak solusi untuk permasalah yang sering dihadapi dalam kehidupan sehari-hari. Adanya aplikasi yang dapat membantu suatu pekerjaan dan membuatnya lebih mudah mendorong perusahaan menggunakan aplikasi untuk membantu pekerjaan dibeberapa departemen seperti administrasi dan sumber daya manusia. Beberapa perusahaan memiliki peraturan mengharuskan karyawan untuk melakukan pekerjaan melebihi batas waktu kerja normal yang disebut lembur. Setiap karyawan yang melakukann lembur akan mendapat upah lembur sesuai dengan jumlah waktu lembur yang telah dilakukan. Tetapi kadang terjadi keterlambatan pembayaran dikarenakan perhitungan upah lembur membutuhkan waktu yang lama saat banyak karyawan melakukan lembur. Untuk menyelesaikan masalah tersebut perusahaan membutuhkan sebuah aplikasi yang dapat melakukan perhitungan upah lembur secara cepat dan akurat, dengan menggunakan algoritma linear search aplikasi akan mencari dan memproses data yang tercatat dimesin absensi, kemudian melakukan perhitungan upah lembur sesuai dengan jumlah waktu lembur yang telah dilakukan. Sehingga dapat meminimalisir terjadinya keterlambatan pembayaran dan menghasilkan perhitungan yang lebih akura.
\end{abstract}

Kata kunci: aplikasi, perusahaan, sumber daya manusia, upah lembur, gaji, otomatisasi 


\section{PENDAHULUAN}

Teknologi informasi merupakan salah satu kebutuhan mendasar hampir di semua sektor bisnis [1] dan salah satu bentuk penerapan dari teknologi informasi adalah aplikasi. Aplikasi dapat digunakan untuk membantu, mempermudah, dan mempercepat suatu pekerjaan. Jaman sekarang untuk memesan makanan, memesan tiket perjalanan, memesan sarana transportasi, membeli barang dan jasa dengan mudah dapat dilakukan menggunakan sebuah aplikasi. Aplikasi dibuat menggunakan bahasa pemrograman dan algoritma tertentu, dibuat sesuai dengan kebutuhan yang telah ditentukan untuk dapat menyelesaikan permasalahan yang ada. Salah satu masalah yang sering dihadapi di dalam perusahaan adalah keterlambatan pembayaran gaji dan upah lembur, dikarenakan banyaknya data yang harus di proses dan terbatasnya sumber daya menyebabkan proses perhitungan gaji dan upah lembur memakan waktu yang lama. Proses perhitungan berawal dari menghitung jumlah waktu lembur karyawan dan kemudian menghitung upah lembur sesuai dengan jumlah waktu lembur yang telah dilakukan, meskipun dalam melakukan perhitungan upah lembur sudah menggunakan aplikasi microsoft excel untuk membantu proses perhitungan tetapi diakarenakan data yang harus diproses tidak sedikit, maka waktu yang dibutuhkan untuk mendapatkan hasil perhitungan upah lembur membutuhkan waktu yang lama, hal ini yang menyebabkan terjadinya keterlambatan pembayaran gaji dan upah lembur. Untuk mengatasi permasalahan tersebut dibutuhkan sebuah aplikasi yang dapat melakukan perhitungan gaji dan upah lembur karyawan secara cepat dan akurat, dan tidak lagi menggunakan microsoft excel untuk melakukan perhitungan upah lembur.

Dengan adanya aplikasi ini diharapkan perhitungan upah lembur tidak membutuhkan waktu yang lama, hasil perhitungan upah lembur lebih akurat, dan dapat menghindari terjadinya keterlambatan pembayaran.

Sebelum melakukan penelitian ini penulis melakukan review terhadap penelitian terdahulu, dasar atau acuan yang berupa teori-teori atau temuan-temuan merupakan hal yang sangat perlu dan dapat dijadikan sebagai data pendukung. Dalam hal ini, fokus penelitian terdahulu yang dijadikan acuan adalah terkait dengan masalah teknologi informasi. Pertama, jurnal dengan judul "Aplikasi Pengajuan Lembur Karyawan Berbasis Web" yang disusun oleh Nilda Tri Putri dan Recha Sundari dari STMIK Bina Sarana Global menyimpulkan bahwa sistem pengajuan lembur karyawan yang berbasis web mempermudah semua pihak dalam membuat proses lembur karyawan tanpa waktu yang lama, memperoleh informasi lembur dan mengakses sistem lembur [2]. Dari penelitian pertama ini penulis memutuskan untuk membuat aplikasi yang berbasis web. Pemrograman web adalah salah satu cara untuk membuat web dengan implementasi kode bahasa pemrograman yang dapat berjalan di server [3]. Bahasa pemogrammanya menggunakan framework laravel, laravel adalah framework MVC open source untuk PHP yang digunakan untuk membangun aplikasi web yang kuat [4]. Kedua, penulis melakukan kajian terhadap jurnal dengan judul "Perancangan Sistem Aplikasi Upah Lembur Karyawan Biro Pengadaan Barang PT Semen Padang" yang disusun oleh Nilda Tri Putri dan Recha Sundari dari UIN Sultan Syarif Kasim Riau menyimpulkan bahwa kelebihan dari sistem aplikasi yang dirancang berdasarkan yang harus dipenuhi terhadap sebuah aplikasi perangkat lunak yang ideal adalah adanya integritas data yang baik karena berdasarkan perbaikan yang dilakukan telah dapat menghubungkan semua aktor dan, sedangkan pada sistem yang lama integritas data hanya sampai pada admin [5].

\section{METODE PENELITIAN}

Metode penelitian yang digunakan adalah Software Development Life Cycle (SDLC). SDLC merupakan sebuah siklus hidup pengembangan perangkat lunak yang terdiri dari beberapa tahapantahapan penting dalam membangun perangkat lunak [6]. Dan untuk metode pengembangan sistem menggunakan salah satu model dari Agile yaitu Extreme Programming dimana dalam pembangunan aplikasinya menggunakan object oriented, aplikasi yang dibangun mengikuti aturanaturan dan hal-hal yang praktis yang disesuaikan dengan 4 langkah dalam extream code diantaranya adalah Planning, Design, Coding, dan Testing [7]. Untuk lebih jelasnya dapat dilihat pada gambar 1 di bawah ini. 


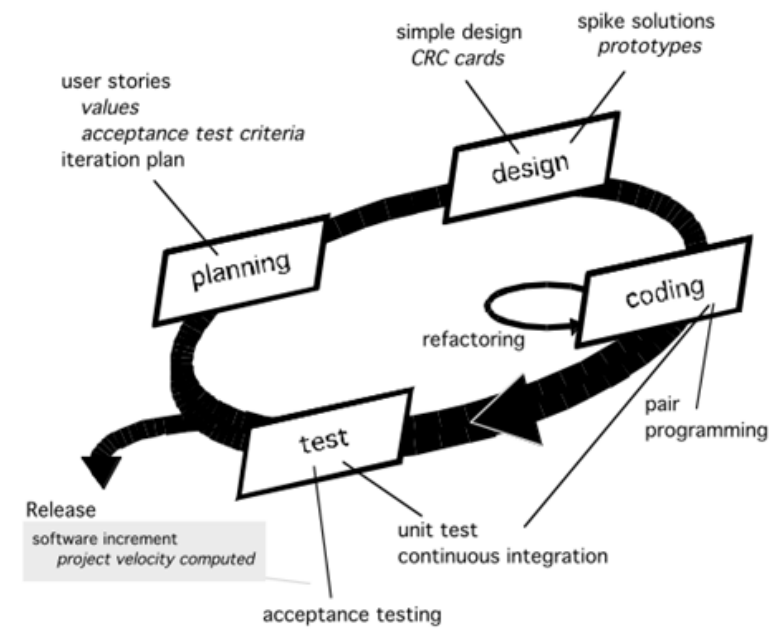

Gambar 1. Agile(Extreme Programming Process) [7]

\subsection{Planning}

Pada Tahap ini penulis menganalisa permasalahan yang dihadapi oleh perusahaan tentang keterlambatan pembayaran upah lembur, kemudian menggambarkan proses yang sedang berjalan saat ini, serta menjabarkan proses dan hasil akhirnya berupa laporan yang diharapkan dari dibuatkannya aplikasi.

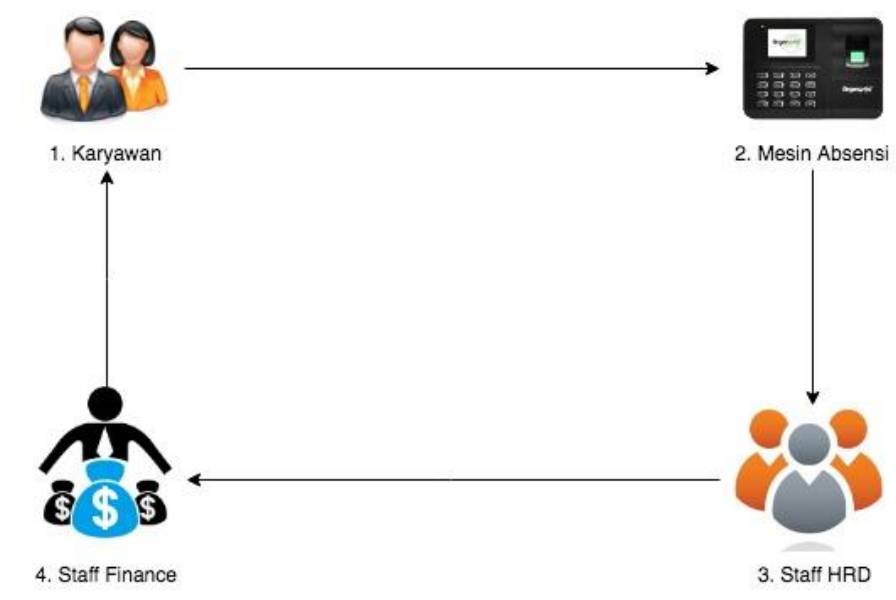

Gambar 2. Proses yang berhalan saat ini

Berdasarkan gambar 2 diatas karyawan pertama kali melakukan absen saat datang dan sebelum meninggalkan kantor yang dicatat oleh mesin absensi fingerprint, kemudian diakhir bulan staff HRD (Human Resource Development) akan melakukan penarikan data dari mesin absensi, selanjutnya dilakukan perhitungan upah lembur sesuai dengan jumlah waktu lembur karyawan, dan terakhir diserahkan ke staff finance untuk dilakukan pembayaran.

\subsection{Design}

Tahap Design pada Extreme Programming (XP) tetap mengusung sebuah pembuatan program maupun pengembangan program yang sederhana, dimana dalam design yang sederhana ini tetap memberikan gambaran secara detil dari permasalahan yang dihadapi. Biasanya dari sisi design akan memberikan simulasi gambaran program yang telah didesign dan dijadikan program sederhana untuk diperlihatkan dan untuk memastikan bahwa kebutuhan perusahaan telah terpenuhi. Adapun dalam tahapan ini dibuatkan use case diagram seperti berikut ini: 


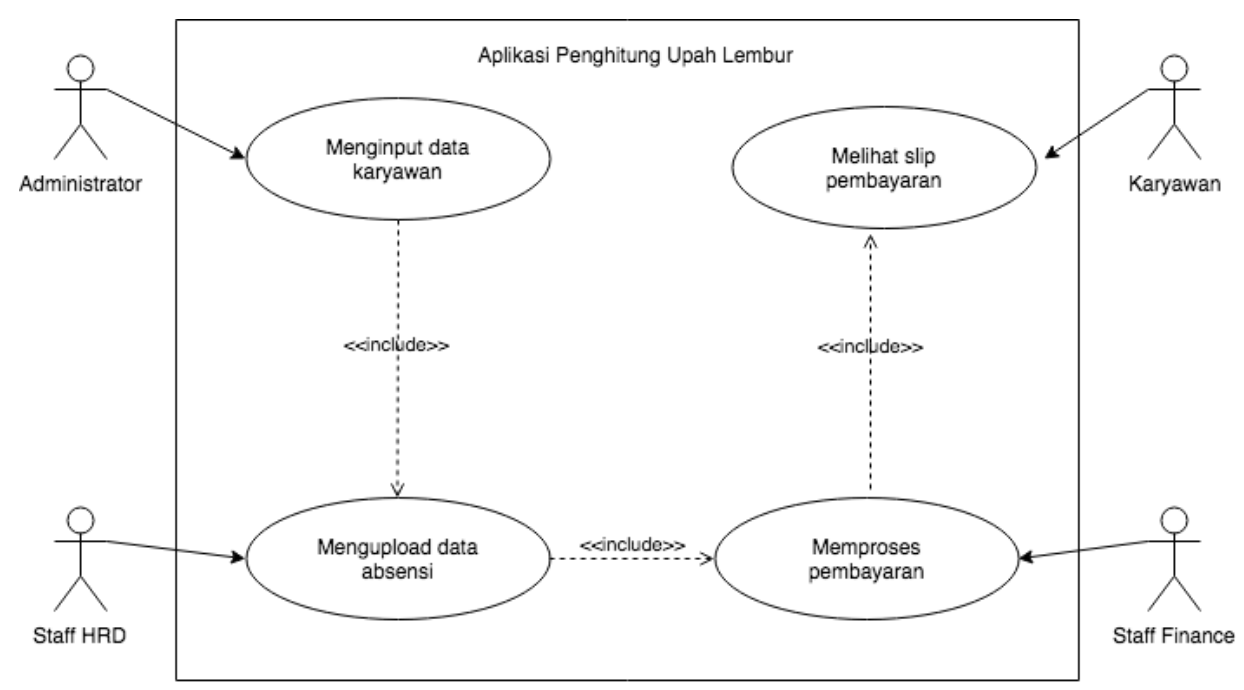

Gambar 3. Use Case Diagram Aplikasi Upah Lembur

Setiap use case merepresentasikan tugas diskrit yang melibatkan interaksi aktor dengan suatu sistem [7]. Dalam use case diagram terdapat 4 aktor yang mempunyai peran masing-masing, diantaranya adalah: Administrator yang bertugas untuk menginput data semua karyawan, Staff $H R D$ mengunggah data absensi yang sebelumnya didapatkan dari mesin absensi fingerprint, Staff Finance akan memverifikasi sebelum melakukan pembayaran upah lembur, dan Karyawan dapat melihat dan mengunduh slip atau bukti pembayaran.

\subsection{Coding}

Pada tahap coding dimulai untuk membangun aplikasi menggunakan Laravel dan database MySQL dengan sistem autentikasi menggunakan login mempunyai 4 user berbeda, yaitu: administrator, karyawan, staff hrd, staff finance. Setiap user memiliki hak akses berbeda sesuai dengan role yang diberikan sehingga satu user memiliki satu role tertentu. Untuk masuk ke aplikasi user harus memasukan email dan password yang telah dibuat oleh administrator dan dikirimkan ke email semua karyawan. Setelah melakukan login, user akan dapat menggunakan aplikasi sesuai dengan role yang sudah ditentukan sebelumnya.

Untuk algoritmanya sendiri penulis menggunakan algoritma linear search yang mana algoritma ini mencari elemen dari array atau daftar terkait dengan memeriksa masing-masing elemen dan membandingkannya dengan elemen pencarian yang dimulai dengan elemen pertama ke elemen terakhir dalam daftar. Jika suatu elemen ditemukan kemudian indeks, sinyal bendera atau nilai dapat dikembalikan atau diproses, jika tidak indeks khusus sebagai -1 atau sinyal bendera dapat dikembalikan [8]

\section{HASIL DAN PEMBAHASAN}

Hasil dari penelitian ini adalah aplikasi penghitung upal lembur karyawan berdasarkan jumlah waktu lembur menggunakan algoritma linear search dan berikut hasil dari aplikasinya. 


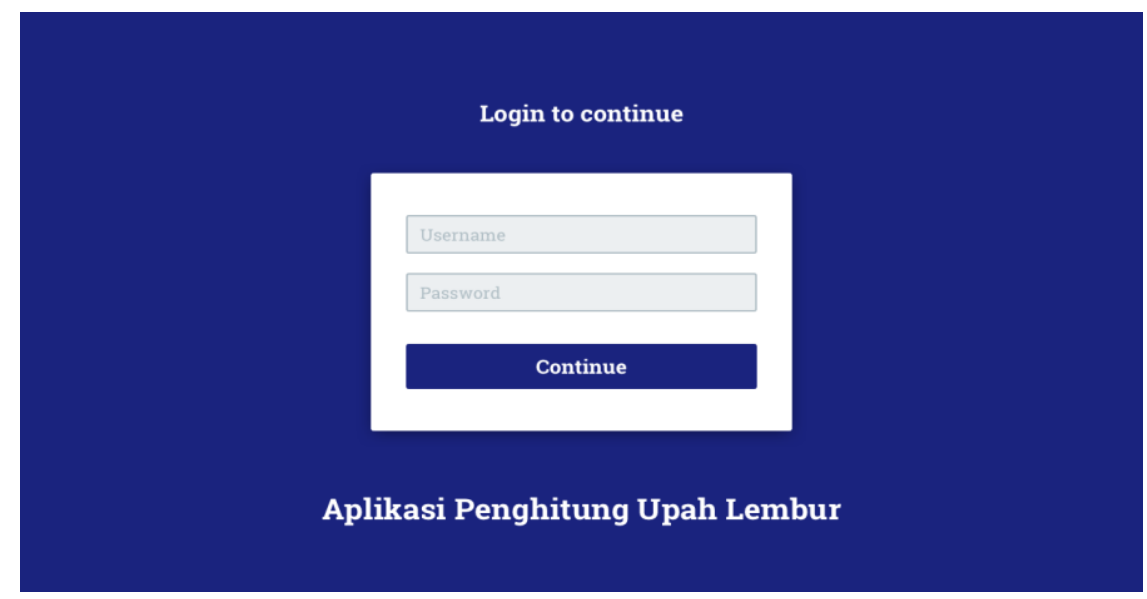

Gambar 4. Halaman Login

Seperti gambar 4 di atas pertama kali aplikasi dibuka akan menampilkan halaman login dimana user harus memasukan email dan password masing-masing, jika berhasil maka akan diarahkan ke halaman yang berisi menu yang dapat diakses masing-masing role.

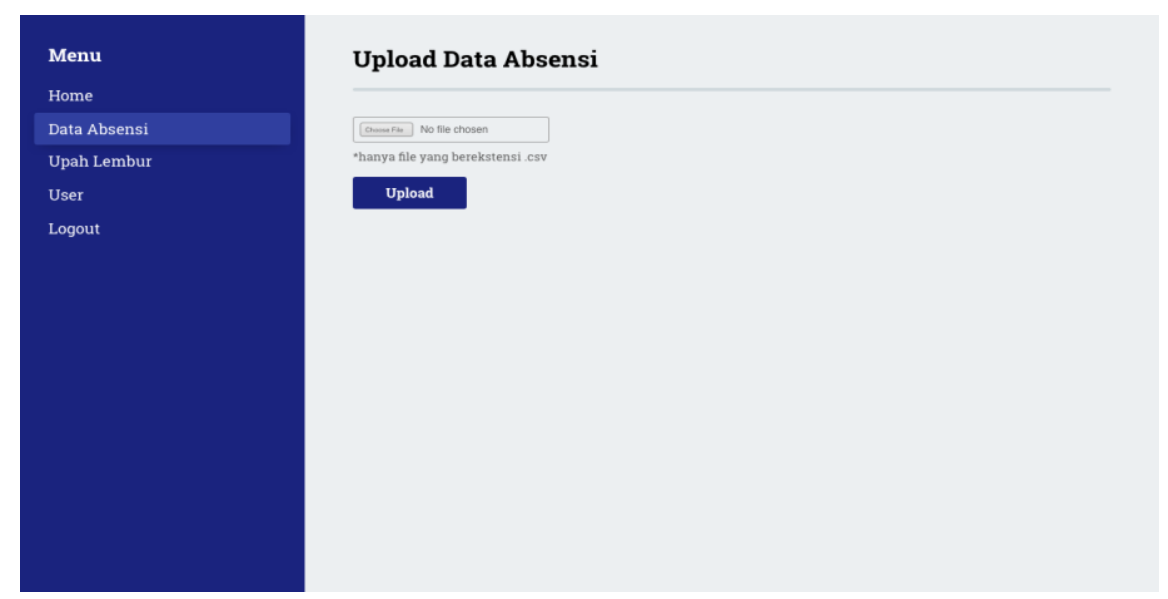

Gambar 5. Halaman Upload Data Absensi

Sebelum melakukan perhitungan staff $H R D$ yang sudah login harus mengunggah data absensi yang berekstensi .csv yang sebelumnya sudah diambil dari mesin absensi fingerprint.

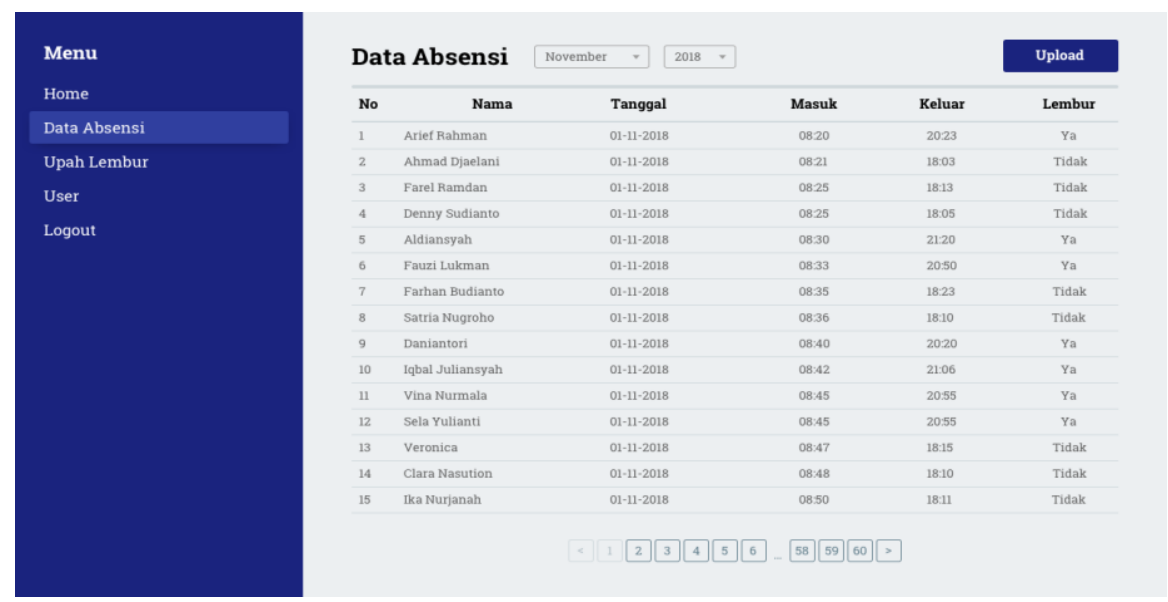

Gambar 6. Halaman Data Absensi 
Setelah data absensi berhasil diunggah, maka akan tampil tabel yang berisi data-data absensi dari setiap karyawan beserta tanggal, jam masuk, jam keluar, dan keterangan apakah dia melakukan lembur atau tidak.

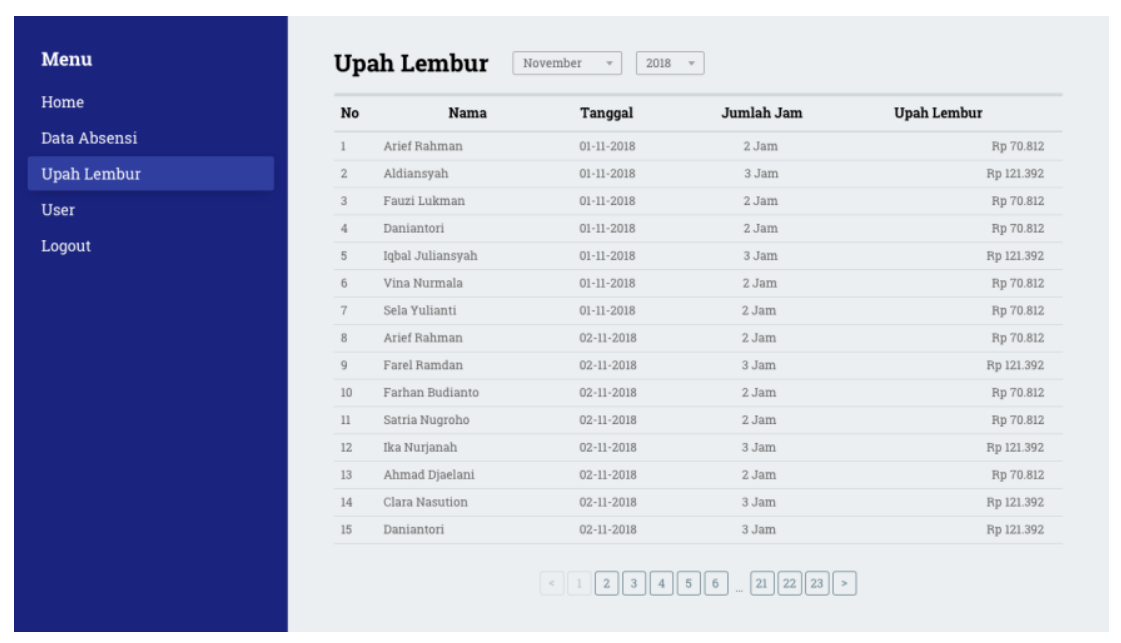

Gambar 7. Halaman Buat User Baru

Dan terakhir jika ada karyawan baru, maka perlu dibuatkan user untuk dapat mengakses aplikasi ini. Untuk mendapatkan hasil yang prima dan sesuai dengan yang diharapkan, maka pengujian aplikasi / perangkat lunak wajib dilakukan. Pengujian aplikasi ini dilakukan dengan melakukan pengecekan langsung dalam aplikasi desuaikan dengan rencana pengujian aplikasi. Dalam tabel 1 dibawah, terdapat berbagai rencana pengujian aplikasi sebagai berikut:

Tabel 1. Hasil Uji Coba Aplikasi

\begin{tabular}{|c|l|l|l|l|}
\hline No & \multicolumn{1}{|c|}{ Deskripsi } & \multicolumn{1}{|c|}{ Kondisi Pertama } & \multicolumn{1}{|c|}{ Uji Coba } & \multicolumn{1}{|c|}{ Hasil } \\
\hline 1 & Halaman login & Melihat halaman login & $\begin{array}{l}\text { Memasukan username } \\
\text { dan password }\end{array}$ & Sukses \\
\hline 2 & $\begin{array}{l}\text { Halaman unggah data } \\
\text { absensi }\end{array}$ & $\begin{array}{l}\text { Melihat } \text { form unggah } \\
\text { data absensi }\end{array}$ & $\begin{array}{l}\text { Menggungah data } \\
\text { absensi (.csv) }\end{array}$ & Sukses \\
\hline 3 & Halaman data absensi & $\begin{array}{l}\text { Melihat tabel data } \\
\text { absensi }\end{array}$ & $\begin{array}{l}\text { Menampilkan data } \\
\text { absensi per bulan }\end{array}$ & Sukses \\
\hline 4 & Halaman upah lembur & $\begin{array}{l}\text { Melihat tabel data } \\
\text { upah lembur }\end{array}$ & $\begin{array}{l}\text { Menampilkan data } \\
\text { upah lembur }\end{array}$ & Sukses \\
\hline 5 & Halaman buat user baru & $\begin{array}{l}\text { Melihat } \text { form } \text { buat } \text { user } \\
\text { baru }\end{array}$ & $\begin{array}{l}\text { Memasukan data } \text { user } \\
\text { baru }\end{array}$ & Sukses \\
\hline
\end{tabular}

\section{KESIMPULAN DAN SARAN}

Berdasarkan penelitian yang telah dilakukan tentang aplikasi penghitung upah lembur berdasarkan jumlah waktu lembur, maka dapat diambil beberapa kesimpulan yaitu:

1. Staff HRD tidak perlu lagi menghitung upah lembur secara manual, dengan menggungah data absensi yang telah diambil dari mesin absensi fingerprint, maka perhitungan jumlah waktu lembur dan upah lembur sudah otomatis dilakukan oleh aplikasi.

2. Staff Finance dapat segera melihat jumlah upah yang harus dibayarkan setelah staff hrd mengunggah data absensi dan dapat segera melakukan pembayaran.

3. Karyawan dapat mengunduh bukti slip pembayaran jika suatu saat nanti dibutuhkan untuk keperluan lain.

4. Admin atau staff HRD dapat membuat $u$ ser baru jika nanti ada karyawan yang baru bergabung dengan perusahaan.

52 | Jurnal PETIR 


\section{DAFTAR PUSTAKA}

[1] Boy Yuliadi, Andi Nugroho, Rancangan Disaster Recovery Pada Instansi Pendidikan Studi Kasus Universitas Mercu Buana, dari Jurnal Teknik Informatika, 2016.

[2] Jesa Ariawan, Sri Wahyuni, Aplikasi Pengajuan Lembur Karyawan Berbasis Web, dari Jurnal Sisfotek Global, 2015.

[3] Sabar Rudiarto, Development Of Blast Email, Chatting, And Sms Features On Employee Data Application Testing Design Coding, dari International Research Journal of Computer Science, 2018.

[4] Anthony Gore, Full-Stack Vue.js 2 and Laravel 5, dari Packt Publishing, 2017.

[5] N. T. Putri and R. Sundari, Perancangan Sistem Aplikasi Upah Lembur Karyawan Biro Pengadaan Barang PT Semen Padang, dari Seminar Nasional Teknologi Informasi, Komunikasi dan Industri, 2017.

[6] Ian Sommerville, Software Engineering, dari Pearson Education, 2010.

[7] Roger S. Pressman, Software Engineering A Practitioners Approach $8^{\text {th }}$ edition, dari Mc-Graw Hill Education, 2015.

[8] Vimal P. Parmar, Comparing Linear Search and Binary Search Algorithms to Search an Element from a Linear List Implemented through Static Array, Dynamic Array and Linked List, dari International Journal of Computer Applications, 2015. 